\title{
Achieving More with Less Water: Alternate Wet and Dry Irrigation (AWDI) as an Alternative to the Conventional Water Management Practices in Rice Farming
}

\author{
Tejendra Chapagain (Corresponding author) \& Andrew Riseman \\ Faculty of Land and Food Systems, University of British Columbia (UBC) \\ 344-2357 Main Mall, Vancouver, BC V6T 1Z4, Canada \\ Tel: 1-604-822-9607_E-mail: tejendra@interchange.ubc.ca \\ Eiji Yamaji \\ Graduate School of Frontier Sciences, University of Tokyo \\ 5-1-5 Kashiwanoha, Kashiwa, Chiba 277-8563, Japan \\ Tel: 81-4-7136-4875Ｅ-mail: yamaji@k.u-tokyo.ac.jp
}

Received: April 30, 2010 Accepted: December 7, 2010 doi:10.5539/jas.v3n3p3

\begin{abstract}
Alternate Wet and Dry Irrigation (AWDI) is a water management system where rice fields are not kept continuously submerged but are allowed to dry intermittently during the rice growing stage. A field experiment was conducted in Chiba, Japan during the rice growing season (May-September) of 2008 to assess AWDI and continuous submerged water management practices for their effects on productivity, the surrounding environment, water savings, and Water Productivity Index (WPI). The impact of age of seedlings and plant spacing were also assessed.

AWDI using the proposed irrigation schedule of 10 wet days alternated with 10 dry days used less water (29\% less water) without significant reduction in grain yield $(7.2 \mathrm{t} / \mathrm{h})$ compared with conventional irrigation $(7.8 \mathrm{t} / \mathrm{h})$. Water Productivity Index was significantly higher in all sub-plots in AWDI treatments. WPI was $1.7 \mathrm{~kg} / \mathrm{m}^{3}$ in AWDI treatments compared to $1.3 \mathrm{~kg} / \mathrm{m}^{3}$ in conventional water management. Additional significant results from AWDI treatment included reduced pest and disease incidence, shortened crop cycle, and reduced lodging. However, slightly higher grain yields were observed in all sub-plots of the conventional irrigation treatment than were observed in the same combinations under AWDI. This underscores the need for further research in defining what constitutes an optimum interval for AWDI considering local soil properties, prevailing climate, and the critical periods during the rice growth cycle when the yield was particularly sensitive to moisture stress.
\end{abstract}

Keywords: Alternate wet and dry irrigation (AWDI), System of rice intensification (SRI), Water savings, Water productivity index (WPI), Split-split plot design (S-SPD)

\section{Introduction}

Water is the single most important component of sustainable rice production, especially in the traditional rice growing areas of Asia. From time immemorial, rice has been grown in lowland areas under flooded conditions. More than 75 percent of the world's rice is produced under these conventional irrigation practices (i.e., continuous flooding) (Van der Hoek et al., 2001). Rice grown under traditional practices in the Asian tropics and subtropics requires between $700-1500 \mathrm{~mm}$ of water per cropping season depending on soil texture (Bhuiyan, 1992). However, this conventional water management method leads to a high amount of surface runoff, seepage, and percolation that can account for between 50-80 percent of the total water input (Sharma, 1989).

Recently, the scarcity of, and competition for, water has been increasing worldwide. By 2025, the per capita available water resources in Asia are expected to decline by 15-54 percent compared with 1990 availability (Guerra et al., 1998). Agriculture's share of water will decline at an even faster rate because of the increasing competition for available water from urban and industrial sectors. Despite the constraints of water scarcity, rice 
production and productivity must rise in order to address the growing demand for rice driven largely by population growth and rapid economic development in Asia. Producing more rice with less water is therefore a formidable challenge for achieving food, economic, social, and water security for the region (Facon, 2000). In other words, the efficiency of water use in irrigated rice production systems must be significantly increased.

One such strategy to address this need is the use of alternate wet/dry irrigation method (AWDI) for cultivated rice. This method is increasingly used in parts of Asia, especially in Japan, China, and India. Contrary to most lowland rice-growing practices used throughout the world, the rice field is not under continuous flooding but instead, is irrigated intermittently during the production period (Van der Hoek et al., 2001). AWDI is one method that can increase the water use efficiency at the field level by reducing seepage and percolation during the production period.

Experience with the System of Rice Intensification (SRI) techniques also shows that farmers who grow irrigated rice with continuous flooding have been wasting large volumes of water (Uphoff, 2006). The SRI is a production system that emphasize the use of younger seedlings ( $<15$ days $)$ planted singly and at wider spacing, together with the adoption of intermittent irrigation, organic fertilization, and active soil aeration to the extent possible (Stoop et al., 2002; Uphoff 2007). The SRI system shows that keeping paddy soils moist but not continuously saturated gives better results, both agronomically and economically, than flooding rice throughout its crop cycle. SRI methods enable farmers to reduce their irrigation by $25-50 \%$ while realizing higher and more profitable production (Uphoff and Randriamiharisoa, 2002; Anthofer, 2004; Namara et al., 2004; Li et al., 2005; Sato, 2005; Uphoff, 2006).

However, good water control and minimal use of water is both the most controversial component in rice farming and the factors most difficult for farmers to regulate. Also, due to the variation in climatic and edaphic factors, results from AWDI methods adopted in one area may not correlate with other areas. The current study, therefore, was undertaken to identify the effects of water level and duration of alternate wetting and drying periods on rice productivity, water savings, and Water Productivity Index in temperate Japan.

\section{Materials and Methods}

\subsection{Study Site}

This study was conducted in Chiba, Japan during 2008-rice season (May to September). The experimental site was situated at $35^{\circ} 52^{\prime} \mathrm{N}$ and $139^{\circ} 59^{\prime} \mathrm{E}$, at an altitude of $11 \mathrm{~m}$ above mean sea level. Research was conducted under natural climatic conditions. The soil was of good fertility and clayey textured having clay: silt: sand percentages of 59: 28: 13, respectively. The soil $\mathrm{pH}$ was 6.4 (Beckman glass electrode $\mathrm{pH}$ meter), organic matter of $2.78 \%$ (Walkey and Black method), total nitrogen content of $0.218 \%$ (Macro-Kjeldahl method), available phosphate $48 \mathrm{mg} \mathrm{P}_{2} \mathrm{O}_{5} / \mathrm{kg}$ of dry soil (Olsen's method), and exchangeable potassium $186 \mathrm{mg} \mathrm{K} \mathrm{O}_{2} \mathrm{O} / \mathrm{kg}$ of dry soil (Neutral normal ammonium acetate method). Soil was homogeneous across the test plots.

\subsection{Experiment Details}

2.2.1 Treatments and their combination: Primary treatment components included were based on results from a previous SRI experiment in Indonesia (Sato and Uphoff, 2007; Keisuke et al., 2007), and common management methods for conventional rice farming in Japan (Horie et al., 2005).

The experiment was conducted using the most popular rice cultivar in Japan, 'Koshihikari', in a split-split plot design (S-SPD) with irrigation method (AWDI and conventional) in the main plots, while age of seedling (14 and 21-day) and spacing (30x30 $\mathrm{cm}^{2}$ and $\left.30 \times 18 \mathrm{~cm}^{2}\right)$ were allocated in the sub and sub-sub plots. Altogether, there were eight treatment combinations replicated thrice (Table 1). Therefore, 24 experimental units, 12 in each main plot, of $15 \mathrm{~m}^{2}$ were laid out to better represent the sets of treatments in S-SPD.

2.2.2 Irrigation management: There were two methods of irrigation in the main plots, AWDI and conventional flooding. The first plot was designed for intermittent irrigation with alternate wet and dry periods whereas the second plot was structured for conventional water management providing continuous submerged condition (up to $5-6 \mathrm{~cm})$ throughout the cropping season.

In general, intermittent irrigation was scheduled at 10-day intervals starting 10 days after transplanting (DAT), up to 75 days. However, irrigation was suspended after 75 DAT as the natural precipitation was sufficient. A simple manual measuring scale and hollow tubes buried to $20 \mathrm{~cm}$ deep were used to measure water depth during wet and dry periods, respectively. Water level was maintained up to $1.5 \mathrm{~cm}$ during the wetting period while fields were allowed to drain naturally during dry periods before resumption of irrigation (Figure 1). Plots were equipped with a pipe irrigation system with proper water inlet and outlet devices for timely irrigation and 
drainage. Plots were watered in the evening of the first day of the wet period while the water was drained in the morning of the first day of the dry period.

For conventional irrigation, plots were equipped with devices for continuous irrigation (up to $5-6 \mathrm{~cm}$ depth) throughout the rice-growing season. A mid summer drainage was allowed by stopping irrigation between 76-85 DAT based on the general practice of the local community (Figure 1).

2.2.3 Other cultural practices: Except for the treatment components (Table 1), all other management practices were constant across test plots. Healthy and vigorous rice seedlings, raised by the farmers under protective environment and with the same level of management, were used for transplantation into test plots. The field site was used in prior years for rice cultivation but with only minimal use of fertilizers and pesticides. The test crop was supplied with bio-organic manure (Blue Trading, Osaka, Japan) with moisture 7\%, $\mathrm{pH} 4.8$, nitrogen (total N) $4.29 \%$, potassium $\left(\mathrm{K}_{2} \mathrm{O}\right) 1.07 \%$, and carbon to nitrogen ratio $(\mathrm{C} / \mathrm{N}) 10$. It was applied as a single application of $1 \mathrm{t} / \mathrm{h}$ upon draining the excess water after puddling and leveling the field. A single dose of bensulfuron-methyl (BSM) and mefenacet granule mixture was applied at $30 \mathrm{~kg} / \mathrm{h}, 5 \mathrm{DAT}$ to control common rice weeds. No further pesticides or fungicides were used on test plots as the pest pressures were below the economic threshold level.

\subsection{Data Collection and Analysis}

2.3.1 Plant-based parameters: Data were recorded for plant height (from soil surface to the tip of apical leaf), number of effective tillers (panicles) per unit area $\left(\mathrm{m}^{2}\right)$, days to flowering and harvest, and grain yield $\left(\mathrm{kg} \mathrm{m}^{-2}\right.$ and $\mathrm{t} \mathrm{h}^{-1}$, respectively). Days to harvest was calculated following harvest at a grain moisture (using a rice grain moisture meter, Model MD7822, Shenzhen Sanpo Instrument Company Ltd., China) of 19-21\% measured in the early afternoon during dry weather conditions (Have, 1967). Grain color was also a determinant of maturity and considered ready for harvest when $80 \%$ of the panicles in the sample plants were straw-colored, and the grains in the lower portions of the panicle were in hard-dough stage.

Plants were scored for lodging resistance before harvest on a $0-10$ scale ( 0 for $100 \%$ erect plants, and 10 for complete lodging of whole plot) based on a visual observation. The degree of lodging of an individual plant (or tiller within a hill) was also assessed. Plants (or tillers) that were completely bent down to the ground (60 to $\left.90^{\circ}\right)$ with all panicles touching the soil surface were considered as completely lodged plants while the plants up to $60^{\circ}$ bending without having panicles' contact to the ground surface were considered as partial lodging. The score value was subjected to mean calculation and later transformed into percentages. The number of healthy (white) and decayed roots (brown/black) were also counted by randomly selecting five plants from two treatment combinations (i.e., AWDI with 14-day seedlings and 30x30 $\mathrm{cm}^{2}$ spacing; flooded plot with 21-day seedlings and $30 \times 18 \mathrm{~cm}^{2}$ spacing), prior to flowering (60 DAT).

2.3.2 Crop management parameters: General observations were made 20,35 and 50 DAT on the type and number of weeds that infested AWDI and conventional plots. Time taken to weed in AWDI and flooded plot was recorded and summed to calculate differences in labor requirements.

In addition, insect pest and disease pressures were quantitatively recorded and assessed with regard to type and nature of damage. Pest density and extent of damage was calculated for the major pest (i.e., leaf folder) to the area by counting the number of larvae and percent leaf damaged throughout the cropping period. These data were used to determine the economic threshold level (10\% of leaf damage during vegetative stage or $5 \%$ of flag damage at flowering, as suggested by Samiayyan et al., 2010) to determine the frequency and timing of subsequent pesticide applications.

2.3.3 Water savings: Water discharge from the irrigation pipe was calculated as the volume of water $\left(\mathrm{m}^{3}\right)$ flowing through the pipe and measured as cubic meter per second $\left(\mathrm{m}^{3} / \mathrm{s}\right)$. The time required to maintaining appropriate water levels in the main plots during each irrigation was noted and summed to calculate the total volume of water applied to the plots throughout the cropping season. Water saving percentage was calculated as follows:

$$
\text { Water Savings }(\%)=\frac{\text { Water Supplied in Flooded Plot }- \text { Water Supplied in AWDI Plot }}{\text { Water Supplied in Flooded Plot }} \times 100
$$

Furthermore, water loss was also calculated based on the amount of water supplied in each plot. A simple measuring scale was used to determine the level of water $(\mathrm{cm})$ lost each day during wetting period.

2.3.4 Water Productivity Index (WPI): Water-use efficiency is intrinsically ambiguous in relation to crop production (Sharma, 1989; Bhuiyan et al., 1995). In this paper, WPI is calculated as the ratio of crop yield ( $\mathrm{kg} / \mathrm{h}$ ) 
per unit water $\left(\mathrm{m}^{3} / \mathrm{h}\right)$ supplied as defined by Jaafar et al. (2000). It includes irrigation, rainfall and antecedent soil moisture.

$$
\text { Water productivity index }(\mathrm{kg} / \mathrm{m} 3)=\frac{\text { Grain Yield }(\mathrm{kg} / \mathrm{h})}{\text { Total Water Supplied }(\mathrm{m} 3 / \mathrm{h})}
$$

2.3.5 Data analysis: Data were compiled and subjected to mean calculation and analysis of variance using Microsoft Excel and MSTAT-C software. Mean separation was done by LSD, and simple correlations were run between selected parameters using Statistical Package for Social Science (SPSS) software wherever necessary.

\section{Results}

\subsection{Hydro-meteorological description of the study area}

Climatic data are summarized for the experimental site during the rice season (May to September) of 2008 (Table 2). Average daily mean temperature was $22.3^{\circ} \mathrm{C}$, with the hottest days $\left(35.9^{\circ} \mathrm{C}\right)$ in August, whereas the average daily minimum temperature was $19.1^{\circ} \mathrm{C}$ during the rice season. The average monthly sunshine hours during the cropping season was 134.6, with maximum in July (163 hours), and the lowest in September (119.2 hours). The rainy season commenced from April and lasted until October. Total precipitation during May to September was $1052 \mathrm{~mm}$, with August receiving the highest (up to $148.5 \mathrm{~mm} /$ day). The relative humidity (RH) rose from March-April (>60\%) and reached to its maximum (80\%) in July-August.

\subsection{Plant based Parameters}

Water management practice showed varied response in vegetative and reproductive characteristics. The significant effect of AWDI was observed in earlier maturity (117 days vs. 121 days in conventional irrigation), reduced plant lodging ( $32 \%$ vs. $80 \%$ in conventional irrigation), and increased Water Productivity Index (1.7 $\mathrm{kg} / \mathrm{m}^{3}$ vs. $1.3 \mathrm{~kg} / \mathrm{m}^{3}$ in conventional irrigation) (Table 3). Other parameters measured between AWDI and conventional irrigation was not different; these included plant height $(122 \mathrm{~cm}$ vs. $130 \mathrm{~cm})$, number of effective tillers (310 vs. 338$)$, grain yield $(7.2 \mathrm{t} / \mathrm{h}$ vs. $7.8 \mathrm{t} / \mathrm{h})$ and Harvest Index $(43 \%$ vs. $44 \%$ in conventional water management).

Key vegetative and yield-related components, as affected by the major treatments and their interactions, are presented (Tables 4, 5, and 6). Significant interactions were observed between the irrigation method and age of seedlings with respect to the number of effective tillers, time to maturity, grain yield, plant lodging percent (PLP) and Water Productivity Index (Table 4). Except for PLP, WPI, and time to maturity, no positive effects of AWDI combined with 14 and 21-day seedlings were observed. The reduced PLP and greater WPI were associated with AWDI when combined with spacing (30x30 and $\left.30 \times 18 \mathrm{~cm}^{2}\right)$ as compared to the same combination under conventional water management (Table 5).

The interaction effects of three major components of the system are summarized (Table 6). Plant height differed between AWDI plots with 21-day seedlings and 30x18 $\mathrm{cm}^{2}$ spacing to that of conventional plot with younger seedlings (14-day) planted at wider spacing $\left(30 \times 30 \mathrm{~cm}^{2}\right)$. Plants in AWDI plots produced fewer tillers than did the same combinations under conventional flooding (Table 6). The AWDI plots required 1-2 more days to begin flowering than in the same treatment combinations in flooded plots. However, the AWDI plots required 3-5 fewer days to mature (Table 6).

The interaction effects on grain yield were seen between the combination of AWDI and 21-day seedlings planted at close spacing $\left(30 \times 30 \mathrm{~cm}^{2}\right)$ to that of flooded irrigation with both sets of seedlings (14 and 21-day) at wider spacing $\left(30 \times 30 \mathrm{~cm}^{2}\right)$ (Table 6). In general, rice yields under AWDI conditions were lower compared to the same combinations in continuously flooded plots. Harvest index was not significantly different by irrigation methods.

\subsection{Crop management parameters}

3.3.1 Weed Pressure: The most common weeds were Cyperus rotundus L. and Sagittaria spp L.. C. rotundus, a narrow leaved weed species, was very common in intermittent plots while Sagittaria spp, a broad leaved weed species, was commonly found in flooded plots. Infestation was most severe at 35 DAT (second weeding) and 50 DAT (third weeding) thereby requiring more labor than the first weeding (20 DAT). It is worth noting that there was no extra time requirement for weeding operation in the AWDI plots compared to the conventional plots.

3.3.2 Pest and disease pressures: AWDI also minimized the incidence of insect pests and diseases compared to the conventional treatment. Rice leaf folder (Cnaphalocrosis medinalis Guenee) was the major pest observed 
during 30-40 DAT whereas seedling blight (Fusarium spp.) was the primary disease observed. In both cases, incidence was less frequent and of a lesser severity in the AWDI plots vs. the conventional plots.

Also, pest damage was more severe in conventional plots planted with 21-day seedlings. Whereas no pests were observed in AWDI plots with 14-day seedlings (Figure 2), disease was a problem in conventionally flooded plots planted with 14-day seedlings (Figure 3).

3.3.3 Effects on crop stand/plant lodging: Among treatments, there were clear differences observed in the percentage of lodged plants at maturity/harvesting stage. In the AWDI plot, the mean value of complete and partial lodging was $32 \%$ compared to $80 \%$ in the conventionally flooded plot (Table 3). Similarly, lodging percent ranged between 7-47\% in AWDI sub-plots whereas lodging percentage was $50-97 \%$ in the flooded sub-plots (Table 4). AWDI clearly enhanced plant stand through the harvest stage thereby requiring less time to harvest with better grain quality (i.e., uneven maturity, discoloration and molding due to contact with the soil).

The effects of AWDI combined with the 14-day seedlings planted singly at wider spacing also promoted a greater number of whitish, healthy and well-functioning roots as compared to conventionally flooded plots combined with 21-day seedlings planted in a hill of four at $30 \times 18 \mathrm{~cm}^{2}$. The average proportion of whitish (functional) and black (decaying and non-functional) roots was 74:26 in AWDI combined with 14-day seedlings planted singly at $30 \times 30 \mathrm{~cm}^{2}$ spacing whereas it was $46: 54$ in the latter case, 60 DAT (i.e., before flowering).

\subsection{Water measurements}

AWDI saved 29\% water as compare to the amount of total water required in the conventionally flooded plot (Table 7). It was observed that rice plants required more water during mid to late vegetative growth stage (i.e., 26-75 DAT) than the early stage of development (1-25 DAT). Our study revealed that water requirement increased gradually until flowering, with some minor fluctuation in intermittently irrigated plots, with an average daily water loss in the conventional plot of $0.7 \mathrm{~cm}$ (1-25 DAT), $0.9 \mathrm{~cm}$ (26-50 DAT) and 1.2 $\mathrm{cm}$ (51-75 DAT) while in the AWDI plot, it was $0.8 \mathrm{~cm}$ (1-25 DAT), $1.1 \mathrm{~cm}$ (26-50 DAT) and 1.0 $\mathrm{cm}$ (51-75 DAT) (Table 7). In the AWDI plot, the soil surface dried to the point of cracking after 3 continuous days of no surface water.

The pattern of water supplied to the intermittent and flooded plots during the early growth stage is shown (Figure 4). A significant amount of water $\left(6.9 \mathrm{~m}^{3}\right)$ was applied to the conventional plot immediately after transplanting (AT) to establish the water depth at 5-6 cm. During the wetting period under AWDI management, irrigation requirement was similar to the conventional plot. However, the water volume was 3-4 times higher in AWDI plot $\left(5.7 \mathrm{~m}^{3}\right)$ when the plot was irrigated immediately after a dry period. This situation lasted for 2-3 days before equilibrating to the same level as it was before the dry period. The highest quantity of water was saved in the AWDI plot during dry periods, i.e., $16-25$ DAT $\left(10.5 \mathrm{~m}^{3}\right)$. The pattern was similar during the late vegetative phase (40-70 DAT).

Water Productivity Index was significantly greater in the AWDI plot compared to conventional irrigation with $1.7 \mathrm{~kg} / \mathrm{m}^{3}$ in the AWDI plot compared to $1.3 \mathrm{~kg} / \mathrm{m}^{3}$ in the conventional plot (Table 3). The interaction effects also displayed a greater response of water to grain production in AWDI plots (Table 4, 5, 6). The lowest $(1.2$ $\left.\mathrm{kg} / \mathrm{m}^{3}\right)$ value was observed under continuous flooding with 21-day old seedlings and close spacing $\left(30 \times 18 \mathrm{~cm}^{2}\right)$ (Table 6). Yields from the conventionally flooded plot were slightly higher $(7.8 \mathrm{t} / \mathrm{h})$ than in AWDI plot $(7.2 \mathrm{t} / \mathrm{h})$, but required more water (Table 3 ).

\section{Discussion}

The observed effects of AWDI on rice production are in agreement with prior research. Numerous studies focused on manipulating the depth and interval of irrigation water have reported that continuous submergence of rice during production is not essential for obtaining high yields.

Bhuiyan and Tuong (1995) concluded that a standing depth of water throughout the season is not needed for high rice yields. They added that about 40-45 percent of the water normally used in irrigating the rice crop in the dry season was saved by applying water in small quantities only to keep the soil saturated throughout the growing season, without sacrificing rice yields. A similar result was obtained by Sato and Uphoff (2008) with the use of intermittent irrigation in SRI management.

Similarly, Hatta (1967), Tabbal et al. (1992), and Singh et al. (1996) reported that maintaining a very thin water layer, at saturated soil condition, or alternate wetting and drying can reduce water applied to the field by about 40-70 percent compared with the traditional practice of continuous shallow submergence, without a significant yield loss. Keisuke et al. (2008) and Davids (1998, Unpublished) also reported a reduced irrigation water requirement for non-flooded rice by 20-50 percent than for flooded rice, with the difference strongly dependent on soil type, rainfall, and water management practices. Davids (1998, Unpublished), however, reported a 
decrease in rice yields under non-flooded conditions that was proportional to the level of water stress experienced by the plants.

Anbumozhi et al. (1998) reported increased water productivity $\left(1.26 \mathrm{~kg} / \mathrm{m}^{3}\right)$ in AWDI plot at $9 \mathrm{~cm}$ ponding depth compared to continuous flooding $\left(0.96 \mathrm{~kg} / \mathrm{m}^{3}\right)$. Mao Zhi $(1993,1996)$ concluded that in Southern China, AWDI for rice should be more widely used because of its potential to conserve water (20-35\% reduction in water use), increase water productivity (from $0.65-0.82 \mathrm{~kg} / \mathrm{m}^{3}$ to $1.18-1.50 \mathrm{~kg} / \mathrm{m}^{3}$ after the application of AWDI), increase rice yield (15-28\%), and potential to improve the root environment (i.e., soil oxygen content increased by $120-200 \%)$.

AWDI also positively affected several production factors including pest pressure and lodging. The low incidence of diseases and pests in the AWDI plot could be due to the creation of a less favorable environment thereby disrupting pest and disease life-cycles. In addition, Chaboussou (2004) reported that SRI plants were more resistant pests and diseases thereby reducing the need for chemical protection. AWDI reduced lodging compared to conventional flooding. Kar et al. (1974) suggested increased lodging in flooded plots may be related to the degeneration of surface roots that grow within the top $5 \mathrm{~cm}$ of the soil.

There is a concern that the AWDI method of water management promotes greater weed populations, thus requiring more labor for weed management. Association-Tefy-Saina (1995) and Rakotomalala (1997) reported that SRI methodology required approximately $38-54 \%$ more labor than conventional methods. According to Rakotomalala (1997), $62 \%$ of the extra labor was needed for weed management while $17 \%$ was for transplanting. However, Anthofer (2004) found no difference in labor inputs between SRI and conventional cultivation. Furthermore, Sinha and Talati (2007) documented an 8\% reduction in labor needed per hectare in SRI compared to the conventional, with a corresponding $67 \%$ increase in net income. No difference in weed-labor input between AWDI and conventional plot in this experiment could be the combined effect of standing water on the field for a fortnight after transplanting, and use of herbicide 10 days after transplanting.

Alternate drying and wetting of the fields allows for good aeration of the soil and better root growth thereby increasing rice yield and water use efficiency (Uphoff, 2006). However, the efficient use of water is the most controversial component in rice farming and also one of the most difficult aspects for farmers to master. In order to achieve the necessary control of water levels, farmers must have a level field and a functioning irrigation system that allows for the precise control of the inflow and outflow of any individual field.

\section{Summary and Conclusion}

Experiments and field testing of the AWDI method of cultivating rice from different parts of the globe have demonstrated the utility of AWDI for water saving in irrigated rice farming. This experiment also indicated that Water Productivity Index increased and that land productivity (i.e., yield per unit of land) did not differ from conventionally flooded irrigation. In addition, AWDI was observed as a suitable method to reduce insect pests of rice without an increase in labor for management. There seems to be a potential to use AWDI as part of an integrated pest and disease management strategy in irrigated rice cultivation. This experiment revealed a possibility of controlling weeds by using single dose of appropriate herbicides, and by maintaining a shallow standing water depth until crop establishment (15 DAT), and subsequently maintaining the alternate wetting and drying periods until maturity.

This field experiment confirms that AWDI is a promising method in irrigated rice cultivation with benefits on water saving and maintaining the productivity comparable to conventional flood irrigation. The increased productivity of water and its resource saving aspects are likely to be the critical factors that will make farmers and other stakeholders adopt AWDI in water-scarce areas. However, it is difficult to draw general conclusions as AWDI methods adopted in a certain area may not transfer to other areas because of variability in topography, soil, and climatic conditions across the rice agro-ecological domains. Therefore, it is important that comparative studies be conducted in different environments to verify this practice as a way to conserve water under conditions of water scarcity while maintaining, or increasing, crop yields.

\section{Acknowledgements}

The authors greatly acknowledge Asian Development Bank-Japan Scholarships Program (ADB-JSP) for funding support. Sincere thanks are due to the laboratory members of agro-environmental engineering (AEE) and collaborating farmer in Kashiwa, Chiba, Japan for their active support and cooperation throughout the field experiment.

\section{References}


Anbumozhi, V., Yamaji, E., \& Tabuchi, T. (1998). Rice crop growth and yield as influenced by changes in ponding water depth, water regime and fertigation level. Agricultural Water Management, 37, 241- 253. doi:10.1016/S0378-3774(98)00041-9, http://dx.doi.org/10.1016/S0378-3774(98)00041-9

Anthofer, J. (2004). Evaluation of the System of Rice Intensification (SRI) in Combodia. [Online] Available: http://www.tropentag.de/2004/abstracts/full/399.pdf (January 12, 2009).

Association-Tefy-Saina. (1995). Couts de Revient Dans les Systmes de Riziculture Divers. Association Tefy Saina, National Workshop on SRI, Antananarivo.

Bhuiyan, S. I. (1992). Water management in relation to crop production: Case study on rice. Outlook on Agriculture, 21, 293-299.

Bhuiyan, S. I., \& Tuong, T. P. (1995). Water use in rice production: Issues, research opportunities and policy implications. Paper presented at the Inter-Center Water Management Workshop, 29-30 September 1995. Colombo, Sri Lanka: International Irrigation Management Institute. Geneva: World Health Organization.

Bhuiyan, S. I., Sattar, M. A., \& Khan, M. A. K. (1995). Improving water use efficiency in rice irrigation through wet seeding. Irrigation Science, 16 (1), 1-8. doi:10.1007/BF00208389, http://dx.doi.org/10.1007/BF00208389

Chaboussou, F. (2004). Healthy crops: A new agricultural revolution. UK: Jon Carpenter Publishing.

Facon, T. (2000). Improving the irrigation service to farmers: a key issue in participatory irrigation management. Paper presented at the Asian Productivity Organization Seminar on Organizational Change for Participatory Irrigation Management, 23-27 October 2000, Manila, Philippines.

Guerra, L. C., Bhuiyan, S. I., Tuong T. P., \& Barker, R. (1998). Producing more rice with less water from irrigated systems. SWIM Paper 5. Sri Lanka, Colombo: International Irrigation Management Institute.

Hatta, S. (1967). Water consumption in paddy field and water saving rice culture in the tropical zone. Japan Journal of Tropical Agriculture, 11, 106-112.

Have, H. T. (1967). Research and breeding for mechanical culture of rice in Surinam (pp. 309). Wageningen: Agricultural Research Reports.

Horie, T., Shiraiwa, T., Homma, K., Katsura, K., Maeda, S., Yoshida, H. (2005). Can yields of lowland rice resume the increases that they showed in the 1980s? Plant Production Science, 8, 257-272. doi:10.1626/pps.8.259, http://dx.doi.org/10.1626/pps.8.259

Jaafar, M. N., Saad, P., \& Vel Arjunan, S. N. (2000). A computational model for water use efficiency in rice production. Jurnal Teknologi Maklumat, 12 (1), 1-13.

Kar, S., Varade, S. B., Subramanyam, T. K., \& Ghildyal, B. P. (1974). Nature and growth pattern of rice root system under submerged and unsaturated conditions. Il Riso, 23, 173-179.

Keisuke, S., Yamaji, E., Sato, S., Budhiharto, P. S., \& Mizoguchi, M. (2007). Sustainability of System of Rice Intensification: Benefits of SRI focusing on effects of intermittent irrigation on yield increase and water savings. In: Proceeding of PAWEES $20076^{\text {th }}$ International Conference on Sustainable Rural Development and Management (pp. 25-37), 18 October 2007. South Korea: Seoul National University.

Li, X. Y., Xu, X. L., \& Li, H. (2005). A socioeconomic assessment of the System of Rice Intensification (SRI): A case study from Xinsheng Village, Jianyang County, Sichuan Province. Centre for Integrated Agricultural Development, China Agricultural University, Beijing.

Mao, Zhi (1993). Principle and technique of water saving irrigation for rice. Hubei Province, People's Republic of China: Wuhan University of Hydraulic and Electric Engineering.

Mao, Zhi (1996). Environmental impact of water-saving irrigation for rice. In Irrigation scheduling: From theory to practice. Proceedings of the ICID/FAO Workshop on Irrigation Scheduling, Rome, Italy, 12-13 September 1995. Rome: FAO.

Namara, R. E., Weligamage, P., \& Barker, R. (2004). Prospects for Adopting System of Rice Intensification in Sri Lanka: A Socioeconomic Perspective. IWMI Research Paper 75. Colombo: International Water Management Institute (IWMI).

Rakotomalala, H. W. (1997). Comparison entre la Rizicullture Traditionnelle et le Systeme de Riziculture Intensive dans La Region de Ranomafana. Science Agronomique. Antananarivo: Universite d'Antananarivo. 
Samiayyan, K., Jayaraj, T., Selvam, S., \& Sivasubramanian, P. (2010). The ecological and economic perspectives of upscaling of rice integrated pest management. Karnataka Journal of Agricultural Science, 23 (1), 42-46.

Sato, S. (2005). System of Rice Intensification (SRI): 3 Years' experience of SRI practice under DISIMP. Paper for Workshop of Integrated Citarum Water Management Project, 4-5 July 2005, Jakarta: Nippon Koei Consultancy Office.

Sato, S., \& Uphoff, N. (2007). A review of on-farm evaluation of system of rice intensification (SRI) methods in eastern Indonesia. CAB Reviews: Perspectives in Agriculture, Veterinary Science, Nutrition and Natural Resources. Wallingford: Commonwealth Agricultural Bureau International.

Sato, S., \& Uphoff, N. (2008). A review of on-farm evaluations of system of rice intensification methods in Eastern Indonesia. Decentralized Irrigation System Improvement Project (DISIMP) in Eastern Region of Indonesia. Nippon Koei Company Limited, Japan.

Sharma, P. K. (1989). Effect of Period Moisture Stress on Water-use Efficiency in Wetland Rice. Oryza, 26, 252-257.

Singh, C. B., Aujla, T. S., Sandhu, B. S., \& Khera, K. L. (1996). Effects of transplanting data and irrigation regime on growth, yield and water use in rice (Oryza sativa) in northern India. Indian Journal of Agricultural Sciences, 66, 137-141.

Sinha, S. K., \& Talati, J. (2007). Productivity impacts of the System of Rice Intensification (SRI): A case study in West Bengal, India. Agricultural Water Management, 87, 55-60. doi:10.1016/j.agwat.2006.06.009, http://dx.doi.org/10.1016/j.agwat.2006.06.009

Stoop, W. A., Uphoff, N., \& Kassam, A. (2002). A review of agricultural research raised by the system of rice intensification (SRI) from Madagascar: Opportunities for improving farming systems for resource-poor farmers. Agricultural Systems, 71, 249-274. doi:10.1016/S0308-521X(01)00070-1, http://dx.doi.org/10.1016/S0308-521X(01)00070-1

Tabbal, D. F., Lampayan, R. M., \& Bhuiyan, S. I. (1992). Water-efficient irrigation technique for rice. In V. V. N. Murty, \& K. Koga (Eds.), Soil and water engineering for paddy field management. Proceedings of the International Workshop on Soil and Water Engineering for Paddy Field Management, 28-30 January. Bangkok, Thailand: Asian Institute of Technology.

Uphoff, N. (2006). The System of Rice Intensification (SRI) as a methodology for reducing water requirements in irrigated rice production. Paper for International Dialogue on Rice and Water: Exploring Options for Food Security and Sustainable Environments, held at IRRI, 7-8 March 2006, Los Baños, Philippines.

Uphoff, N. (2007). The System of Rice Intensification: Using alternative cultural practices to increase rice production and profitability from existing yield potentials. International Rice Commission Newsletter, Number 55, U.N. Food and Agriculture Organization, Rome.

Uphoff, N., \& Randriamiharisoa, R. (2002). Reducing water use in irrigated rice production with the Madagascar System of Rice Intensification (SRI). In: Bouman et al. (Eds.). Water-wise Rice Production (pp. 71-87). Los Baños: International Rice Research Institute (IRRI).

Van der Hoek, W., Sakthivadivel R., Renshaw, M., Silver, J. B., Birley, M. H., \& Konradsen, F. (2001). Alternate wet/dry irrigation in rice cultivation: A practical way to save water and control malaria and Japanese encephalitis? Research Report 47, Colombo: International Water Management Institute.

Table 1. Treatment details during 2008-rice season in Chiba, Japan

\begin{tabular}{|c|c|c|c|c|c|}
\hline Treatments & $\begin{array}{c}\text { Irrigation Methods } \\
\text { (main plot) }\end{array}$ & $\begin{array}{c}\text { Age of } \\
\text { Seedlings } \\
\text { (days) }\end{array}$ & $\begin{array}{c}\text { Number of } \\
\text { Seedlings } \\
\text { per Hill }\end{array}$ & Spacing $\left(\mathrm{cm}^{2}\right)$ & $\begin{array}{c}\text { Plant Population } \\
\left(\mathrm{m}^{2}\right)\end{array}$ \\
\hline $\mathrm{T}_{1}$ & AWDI & 14 & 1 & $30 \times 30$ & 11.1 \\
$\mathrm{~T}_{2}$ & AWDI & 14 & 1 & $30 \times 18$ & 18.5 \\
$\mathrm{~T}_{3}$ & AWDI & 21 & 4 & $30 \times 30$ & 44.4 \\
$\mathrm{~T}_{4}$ & AWDI & 21 & 4 & $30 \times 18$ & 74 \\
$\mathrm{~T}_{5}$ & Conventional Flooding & 14 & 1 & $30 \times 30$ & 11.1 \\
$\mathrm{~T}_{6}$ & Conventional Flooding & 14 & 1 & $30 \times 18$ & 4.5 \\
$\mathrm{~T}_{7}$ & Conventional Flooding & 21 & 4 & $30 \times 30$ & 74.4 \\
$\mathrm{~T}_{8}$ & Conventional Flooding & 21 & 4 & $30 \times 18$ & 74 \\
\hline
\end{tabular}

\footnotetext{
${ }^{1}$ Alternate Wet and Dry Irrigation
} 
Table 2. Meteorological data during the rice season of 2008 in Chiba Japan

\begin{tabular}{|c|c|c|c|c|c|c|}
\hline \multirow[t]{2}{*}{ Months } & \multicolumn{2}{|c|}{ Rainfall } & \multicolumn{3}{|c|}{ Temperature $\left({ }^{\circ} \mathrm{C}\right)$} & \multirow{2}{*}{$\begin{array}{l}\text { Sunshine } \\
\text { (hrs) }\end{array}$} \\
\hline & Total & $\begin{array}{c}\text { Daily } \\
\text { Maximum }\end{array}$ & Daily Mean & Daily Maximum & $\begin{array}{c}\text { Daily } \\
\text { Minimum }\end{array}$ & \\
\hline May & 215 & 70 & 17.3 & 21.6 & 13.7 & 141.5 \\
\hline June & 200 & 67.5 & 20.2 & 24.2 & 16.9 & 113.9 \\
\hline July & 99 & 38.5 & 25.6 & 30.4 & 22.3 & 163 \\
\hline August & 386.5 & 148.5 & 25.7 & 30.1 & 22.6 & 135.3 \\
\hline September & 151.5 & 40.5 & 22.9 & 27.2 & 19.9 & 119.2 \\
\hline Average & 210.4 & 73 & 22.34 & 26.7 & 19.08 & 134.58 \\
\hline
\end{tabular}

Source: Abiko Meteorological Station, Abiko, Chiba, Japan

Table 3. Effects of irrigation methods on vegetative and reproductive characteristics during the rice season, 2008

\begin{tabular}{|l|c|c|c|c|c|c|c|c|}
\hline Treatments & $\begin{array}{c}\text { Plant } \\
\text { Height }(\mathrm{cm})\end{array}$ & $\begin{array}{c}\text { No. of } \\
\text { Effective } \\
\text { Tillers } / \mathrm{m}^{2}\end{array}$ & $\begin{array}{c}\text { Time to } \\
\text { Flowering } \\
(\text { days })\end{array}$ & $\begin{array}{c}\text { Time to } \\
\text { Maturity } \\
(\text { days })\end{array}$ & $\begin{array}{c}\text { Grain } \\
\text { Yield } \\
(\mathrm{t} / \mathrm{h})\end{array}$ & $\begin{array}{c}\text { Harvest } \\
\text { Index } \\
(\%)\end{array}$ & $\begin{array}{c}\text { PLP }^{2} \\
(\%)\end{array}$ & $\begin{array}{c}\mathrm{WPI}^{3} \\
\left(\mathrm{~kg} / \mathrm{m}^{3}\right)\end{array}$ \\
\hline AWDI $^{1}$ & 122 & 310 & 74 & 117 & 7.2 & 43 & 32 & 1.7 \\
Conventional & 130 & 338 & 73 & 121 & 7.8 & 44 & 80 & 1.3 \\
SE $( \pm)$ & 3.26 & 9.80 & 0.91 & 1.08 & 0.20 & 1.82 & 4.92 & 0.07 \\
LSD $_{0.05}$ & NS & NS & NS & 3.25 & NS & NS & 14.75 & 0.22 \\
\hline
\end{tabular}

${ }^{1}$ Alternate Wet and Dry Irrigation, ${ }^{2}$ Plant Lodging Percentage, ${ }^{3}$ Water Productivity Index

Table 4. Interaction effects of irrigation methods and age of seedlings on vegetative and reproductive characteristics during the rice season, 2008

\begin{tabular}{|c|c|c|c|c|c|c|c|c|c|}
\hline $\begin{array}{l}\text { Irrigation } \\
\text { Methods }\end{array}$ & $\begin{array}{l}\text { Age of } \\
\text { Seedlings } \\
\text { (days) }\end{array}$ & $\begin{array}{l}\text { Plant } \\
\text { Height } \\
(\mathrm{cm})\end{array}$ & $\begin{array}{c}\text { No. of } \\
\text { Effective } \\
\text { Tillers } / \mathrm{m}^{2}\end{array}$ & $\begin{array}{l}\text { Time to } \\
\text { Flowering } \\
\text { (days) }\end{array}$ & $\begin{array}{l}\text { Time to } \\
\text { Maturity } \\
\text { (days) }\end{array}$ & $\begin{array}{l}\text { Grain } \\
\text { Yield } \\
(\mathrm{t} / \mathrm{h})\end{array}$ & $\begin{array}{c}\text { Harvest } \\
\text { Index } \\
(\%)\end{array}$ & $\begin{array}{l}\text { PLP }^{2} \\
(\%)\end{array}$ & $\begin{array}{c}\mathrm{WPI}^{3} \\
\left(\mathrm{~kg} / \mathrm{m}^{3}\right)\end{array}$ \\
\hline $\begin{array}{l}\text { AWDI }^{1} \\
\text { Conventional }\end{array}$ & $\begin{array}{l}14 \\
21 \\
14 \\
21\end{array}$ & $\begin{array}{l}124 \\
121 \\
133 \\
127\end{array}$ & $\begin{array}{l}272 \\
348 \\
304 \\
372\end{array}$ & $\begin{array}{l}75 \\
74 \\
73 \\
72\end{array}$ & $\begin{array}{l}118 \\
117 \\
122 \\
121\end{array}$ & $\begin{array}{l}7.4 \\
7.0 \\
7.9 \\
7.7\end{array}$ & $\begin{array}{l}44 \\
41 \\
46 \\
42\end{array}$ & $\begin{array}{l}27 \\
37 \\
65 \\
95\end{array}$ & $\begin{array}{l}1.7 \\
1.7 \\
1.3 \\
1.3\end{array}$ \\
\hline $\begin{array}{l}\text { SE }( \pm) \\
\text { LSD }_{0.05}\end{array}$ & & $\begin{array}{c}4.29 \\
\text { NS }\end{array}$ & $\begin{array}{l}11.78 \\
35.35\end{array}$ & $\begin{array}{l}1.64 \\
\text { NS }\end{array}$ & $\begin{array}{l}1.47 \\
4.40\end{array}$ & $\begin{array}{l}0.21 \\
0.62\end{array}$ & $\begin{array}{l}2.43 \\
\mathrm{NS}\end{array}$ & $\begin{array}{c}5.69 \\
17.10\end{array}$ & $\begin{array}{l}0.08 \\
0.25\end{array}$ \\
\hline
\end{tabular}

${ }^{1}$ Alternate Wet and Dry Irrigation, ${ }^{2}$ Plant Lodging Percentage, ${ }^{3}$ Water Productivity Index

Table 5. Interaction effects of irrigation methods and spacing on vegetative and reproductive characteristics during the rice season, 2008

\begin{tabular}{|l|c|c|c|c|c|c|c|c|c|}
\hline $\begin{array}{c}\text { Irrigation } \\
\text { Methods }\end{array}$ & $\begin{array}{c}\text { Spacing } \\
\left(\mathrm{cm}^{2}\right)\end{array}$ & $\begin{array}{c}\text { Plant } \\
\text { Height } \\
(\mathrm{cm})\end{array}$ & $\begin{array}{c}\text { No. of } \\
\text { Effective } \\
\text { Tillers/m }\end{array}$ & $\begin{array}{c}\text { Time to } \\
\text { Flowering } \\
(\text { days })\end{array}$ & $\begin{array}{c}\text { Time to } \\
\text { Maturity } \\
(\text { days })\end{array}$ & $\begin{array}{c}\text { Grain } \\
\text { Yield } \\
(\mathrm{t} / \mathrm{h})\end{array}$ & $\begin{array}{c}\text { Harvest } \\
\text { Index } \\
(\%)\end{array}$ & $\begin{array}{c}\mathrm{PLP}^{2} \\
(\%)\end{array}$ & $\begin{array}{c}\mathrm{WPI}^{3} \\
\left(\mathrm{~kg} / \mathrm{m}^{3}\right)\end{array}$ \\
\hline \multirow{3}{*}{ AWDI $^{1}$} & $30 \times 30$ & 124 & 300 & 74 & 118 & 7.4 & 44 & 27 & 1.7 \\
& $30 \times 18$ & 120 & 320 & 75 & 118 & 7.1 & 42 & 37 & 1.7 \\
Conventional & $30 \times 30$ & 132 & 320 & 73 & 121 & 8.0 & 45 & 73 & 1.3 \\
& $30 \times 18$ & 128 & 355 & 72 & 121 & 7.6 & 43 & 87 & 1.3 \\
\hline SE $( \pm)$ & & 4.18 & 11.78 & 1.79 & 1.37 & 0.22 & 2.01 & 5.58 & 0.09 \\
LSD $_{0.05}$ & & NS & 35.35 & NS & NS & 0.67 & NS & 16.75 & 0.27 \\
\hline
\end{tabular}

${ }^{1}$ Alternate Wet and Dry Irrigation, ${ }^{2}$ Plant Lodging Percentage,${ }^{3}$ Water Productivity Index 
Table 6. Mean values as affected by AWDI and Conventional irrigation practice combined with different age of seedlings and spacing in Chiba, 2008

\begin{tabular}{|c|c|c|c|c|c|c|c|c|c|c|}
\hline $\begin{array}{l}\text { Irrigation } \\
\text { Methods }\end{array}$ & $\begin{array}{c}\text { Age of } \\
\text { Seedlings } \\
\text { (days) }\end{array}$ & $\begin{array}{c}\text { Spacing } \\
\left(\mathrm{cm}^{2}\right)\end{array}$ & $\begin{array}{l}\text { Plant } \\
\text { Height } \\
(\mathrm{cm}) \\
\end{array}$ & $\begin{array}{l}\text { Effective } \\
\text { Tillers } / \mathrm{m}^{2}\end{array}$ & $\begin{array}{l}\text { Time to } \\
\text { Flowering } \\
\text { (days) }\end{array}$ & $\begin{array}{l}\text { Time to } \\
\text { Maturity } \\
\text { (days) }\end{array}$ & $\begin{array}{l}\text { Grain } \\
\text { Yield } \\
(\mathrm{t} / \mathrm{h})\end{array}$ & $\begin{array}{l}\text { Harvest } \\
\text { Index } \\
(\%) \\
\end{array}$ & $\begin{array}{l}\text { PLP }^{2} \\
(\%)\end{array}$ & $\begin{array}{c}\mathrm{WPI}^{3} \\
\left(\mathrm{~kg} / \mathrm{m}^{3}\right)\end{array}$ \\
\hline \multirow{4}{*}{$\mathrm{AWDI}^{1}$} & \multirow{2}{*}{14} & $30 \times 30$ & 125 & 259 & 75 & 118 & 7.4 & 45 & 7 & 1.7 \\
\hline & & $30 \times 18$ & 122 & 286 & 75 & 119 & 7.3 & 43 & 47 & 1.7 \\
\hline & \multirow{2}{*}{21} & $30 \times 30$ & 122 & 340 & 73 & 118 & 7.3 & 42 & 47 & 1.7 \\
\hline & & $30 \times 18$ & 119 & 356 & 74 & 117 & 6.8 & 40 & 27 & 1.6 \\
\hline \multirow{4}{*}{ Conventional } & \multirow{2}{*}{14} & $30 \times 30$ & 136 & 269 & 73 & 122 & 8.0 & 47 & 50 & 1.4 \\
\hline & & $30 \times 18$ & 131 & 338 & 72 & 121 & 7.8 & 44 & 80 & 1.3 \\
\hline & \multirow{2}{*}{21} & $30 \times 30$ & 129 & 372 & 72 & 121 & 7.9 & 43 & 97 & 1.3 \\
\hline & & $30 \times 18$ & 126 & 372 & 73 & 121 & 7.4 & 41 & 93 & 1.2 \\
\hline \multicolumn{3}{|c|}{$\mathrm{SE}( \pm)$} & 5.27 & 14.08 & 1.81 & 2.16 & 0.32 & 2.91 & 7.76 & 0.10 \\
\hline \multicolumn{3}{|c|}{$\mathrm{LSD}_{0.05}$} & 15.80 & 42.25 & NS & NS & 0.95 & NS & 23.68 & 0.30 \\
\hline
\end{tabular}

${ }^{1}$ Alternate Wet and Dry Irrigation, ${ }^{2}$ Plant Lodging Percentage, ${ }^{3}$ Water Productivity Index

Table 7. Water budgeting in the experimental plots $\left(180 \mathrm{~m}^{2}\right)$ through the cropping season (May to September 2008) in Chiba Japan

\begin{tabular}{|c|c|c|c|c|c|}
\hline $\begin{array}{c}\text { Days after transplanting } \\
(\text { DAT })\end{array}$ & \multicolumn{2}{|c|}{ Water supplied $\left(\mathrm{m}^{3}\right)$} & $\begin{array}{c}\text { Water Balance } \\
\left(\mathrm{m}^{3}\right)\end{array}$ & \multicolumn{2}{c|}{ Daily Water Loss (cm) } \\
\hline & Conventional & AWDI $^{1}$ & & Conventional & AWDI $^{1}$ \\
\hline $01-25$ & 30.2 & 17.7 & 12.5 & $0.4-1.0(0.7)$ & $0.6-1.0(0.8)$ \\
\hline $26-50$ & 37.8 & 34.8 & 3.0 & $0.6-1.2(0.9)$ & $0.8-1.4(1.1)$ \\
\hline $51-75$ & 39.3 & 23.9 & 15.4 & $0.8-1.6(1.2)$ & $0.8-1.2(1.0)$ \\
\hline Total & 107.3 & 76.4 & $30.9(29 \%)$ & Average: $0.93 \mathrm{~cm}$ & Average: $0.96 \mathrm{~cm}$ \\
\hline
\end{tabular}

${ }^{1}$ Alternate Wet and Dry Irrigation

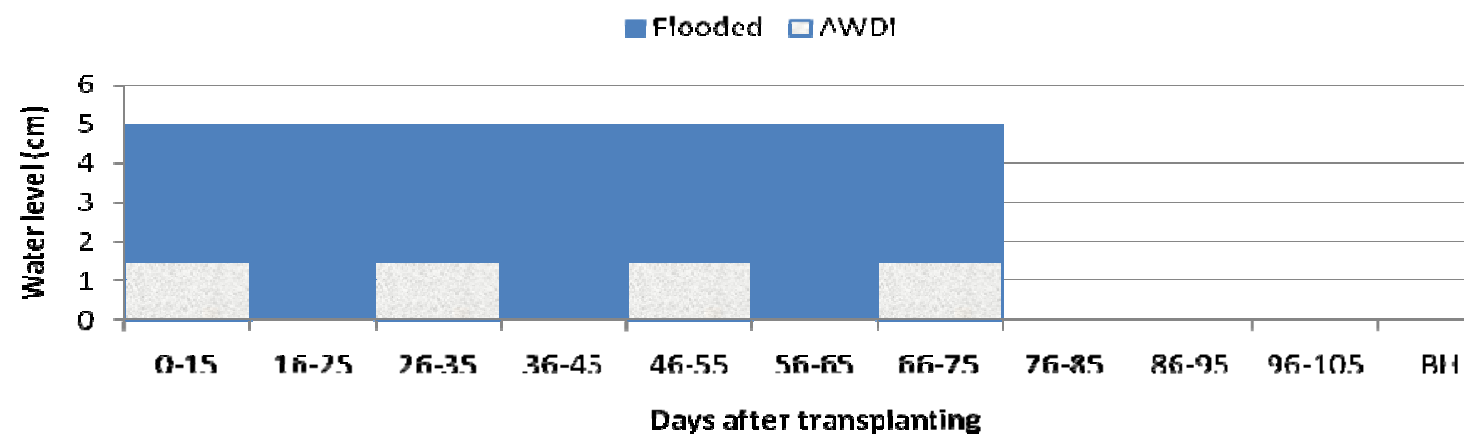

Figure 1. Irrigation schedule in intermittent and flooded plots during 2008- rice season

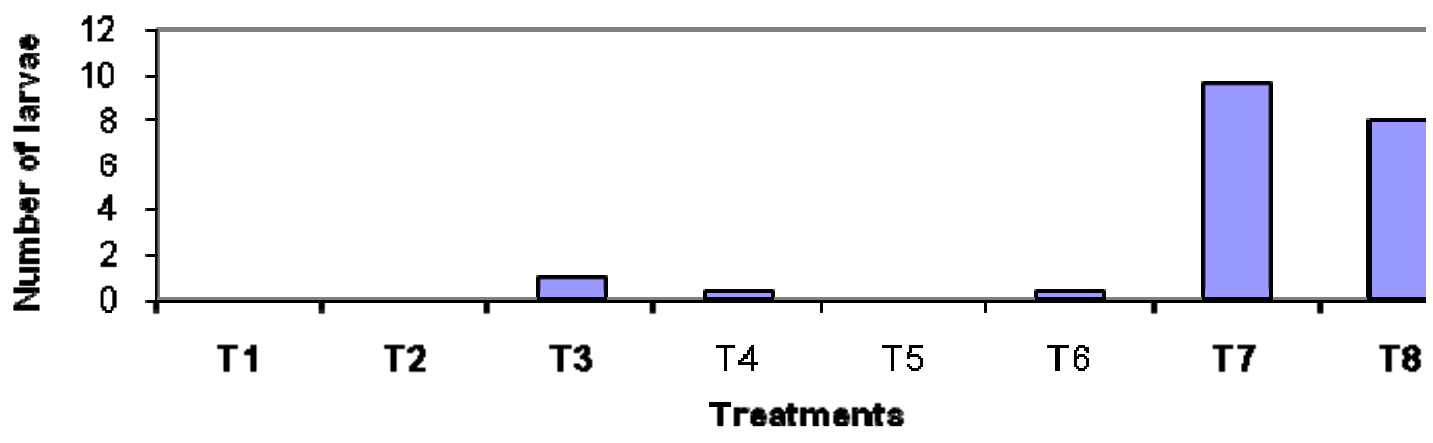

Figure 2. Larvae of Rice leaf folder in different treatments, 35 DAT 


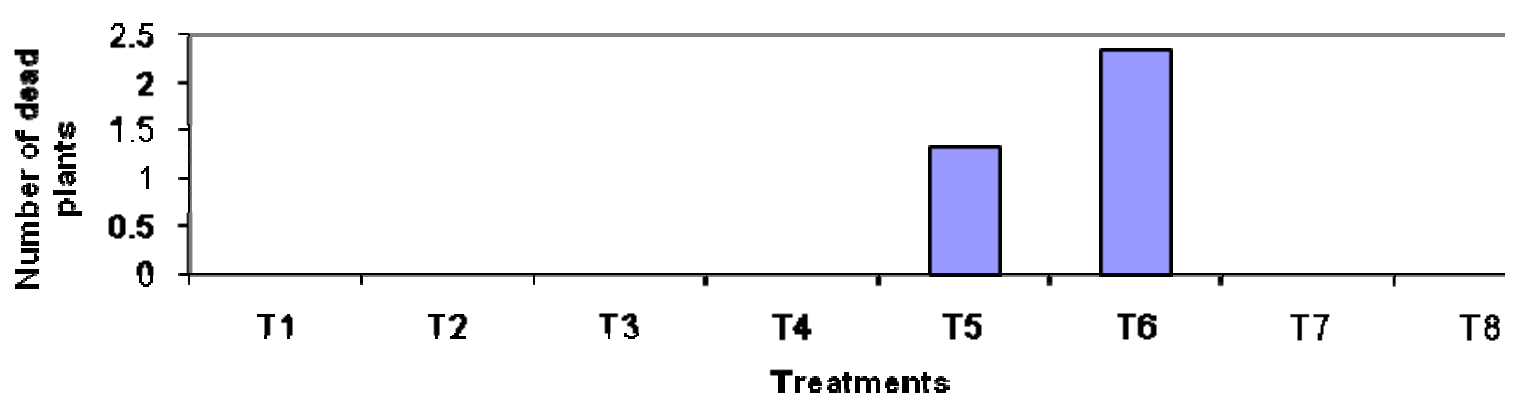

Figure 3. Plants affected by seedling blight disease in different treatments
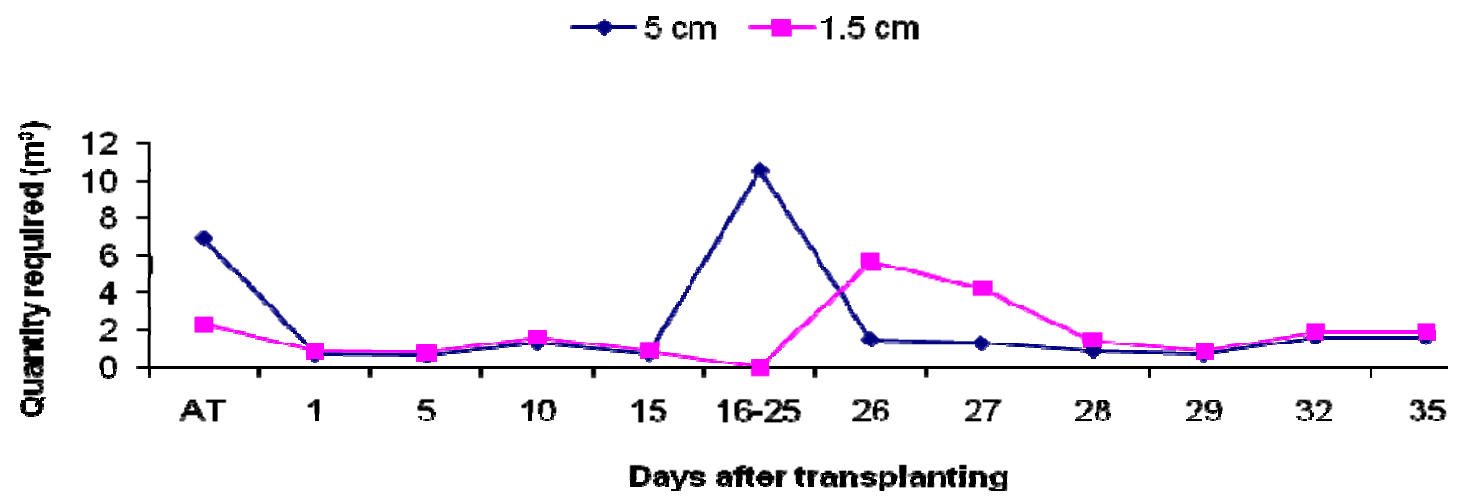

Figure 4. Water supplied to the intermittent and flooded plots during early growth stage in 2008-rice season 